\title{
PENGEMBANGAN BASIS DATA UNTUK MENGELOLA KOMPONEN PERKAKAS BANTU PERAKITAN
}

\section{Suwarsono 1}

\begin{abstract}
Welding assembly jig company's activities are classified as job-order. Their products (jigs \& fixtures) were depending on type of product, which was assembled. There are loot-of variations of product designs, process planning, tools, shop-floor control etc. to handling all customer order. One of the solutions is standardization product, to reduce product variation and the control problems.

The other side, clause 4.8 in ISO $9000: 1994$; Where appropriate, the supplier shall establish and maintain document procedures for identifying the product by suitable means from receipt and during all stages of production, delivery and installation. Where and to extent that trace-ability is a specified requirement, the supplier shall establish and maintain documented procedures for unique identification of individual product or batches. This identification shall be recorded. So they have to develop product/part classification, codification system for identifications all products. This coding system, supported by computer data-base, will helps them to design, plan and control production activity.
\end{abstract}

\section{PENDAHULUAN}

Karakteristik perusahaan perkakas bantu (jig and fixture), jika dilihat dari tipe produksi, termasuk dalam kelompok jobshop production. Yang mana, produk selalu berubah/ berbeda meskipun untuk produk yang sejenis. Sehingga setiap produk selalu memerlukan perhitungan, approval, dan gambar baru sesuai permintaan, sedangkan waktu yang disediakan relatif sempit. Semakin beragam produk yang dibuat, maka semakin banyak dan rumit pula penanganan administrasi rancang bangun. Pencarian suatu kelengkapan dokumen merupakan masalah tersendiri, misalnya tidak lengkap, atau keliru kelompok produknya.
Di sisi lain, keadaan tersebut menyebabkan tahap estimasi penawaran menjadi rawan. Karena hasil kompromi antara ketelitian perhitungan biaya dan waktu penyelesaian produk belum matang. Permasalahan tersebut biasanya dihadapi oleh perusahaan yang kurang maju, sehingga dalam banyak kasus penawaran, harga produk hanya berdasarkan berat produk jadi.

Jika dikaji secara fungsional, produk tersebut memiliki variasi fungsi yang kecil/sedikit. Untuk itu perlu kajian yang menitik beratkan pada usaha perubahan tipe produksi mendekati sifat batch production. Dengan demikian perlu peralatan khusus dan perkakas bantu tambahan, sehingga kecepatan produksi dapat ditingkatkan 
dengan mutu yang baik, tanpa memerlukan tingkat keahlian operator yang tinggi.

Pemasalahan yang dibahas dalam tugas ini adalah kasus yang terjadi di Perusahaan Welding Assembly Jig (perkakas bantu perakitan dengan las) untuk bodi mobil, khususnya jenis kendaraan penumpang pribadi dan niaga, di Bandung. Perusahaan tersebut adalah suatu perusahaan manufaktur yang bersifat Job Shop.

Masalah yang sering terjadi di sana, berkaitan dengan pengelolaan produk, selama ini adalah :

1. Part yang beredar di shop-floor cukup banyak. Dalam satu tahun bisa menerima 10 order (proyek), yang masing-masing bervariasi antara 10 30 jig. Setiap jig terdiri dari sekitar 400 part (kom-ponen, artikel), baik part tunggal maupun part rakitan. Jika pada suatu waktu perusahaan menangani 2 proyek yang bersamaan, maka dalam saat yang sama di bengkel beredar \pm 16.000 part. Tanpa adanya tanda-tanda khusus akan sangat sulit mengetahui jenis dan kelompok rakitan dari masing-masing part.

2. Penulisan Bill of Material (BOM, Partlist) yang berulang dan berbedabeda untuk beberapa unit kerja, cukup rawan terhadap kesalahan penulisan. Yang berakibat pada kesalahan bentuk atau jumlah part yang dipesan. Penggunaan basis data bisa membantu mengurangi resiko tersebut.

3. Seperti halnya perusahaan yang bersifat job-order, produk yang dihasilkan juga beragam, lagi pula pelanggan biasanya membuat rancangan produk sendirisendiri. Jika diperhatikan secara seksama, beberapa part memiliki fungsi dan bentuk fisik yang serupa Kesamaan part dari beberapa produk seperti ini bisa dikelompokkan dalam kelas-kelas (group, family), sehingga bisa distandarkan (dibakukan).

4. Sesuai dengan salah satu persyaratan ISO 9000 atau SNI 19000 (Sistem Manajemen Mutu) klausul 4.8, yang menyatakan bahwa setiap part harus teridentifikasi dan bisa ditelusur sejarahnya; siapa pembuatnya, kapan dibuat, dibuat dengan mesin mana, siapa pengirim material, siapa pemesan, jika dibuat di luar perusahaan harus bisa dilacak sejarah pembuatannya.

Tujuan tulisan ini adalah memberi alternatif langkah-langkah perbaikan untuk mengurangi permasalahan tersebut. Yaitu: Pemberian nomor identitas untuk setiap part yang digunakan dan mengembangkan sistem dokumentasi yang lengkap, dalam bentuk basis data. Basis data yang dikembangkan dalam tugas ini masih berupa langkah awal untuk memenuhi persyaratan, di mana setiap part harus bisa diidentifikasi.

\section{TINJAUAN PUSTAKA}

\section{Manajemen Basis Data Relasional}

Tujuan utama memiliki suatu basis data, bagi sebuah perusahaan, adalah untuk memudahkan mengelola dan mencari data. 
Beberapa query (permintaan informasi) akan dilakukan pada basis data untuk mendukung pengambilan keputusan yang berkaitan dengan analisis permasalahan yang ada.

Basis data relasional adalah basis data yang menggunakan model data relasional. Fungsi model data adalah untuk mengubah informasi yang ada di $E-R$ diagram menjadi struktur data yang dimengerti oleh DBMS (Database Management System).

Perancangan basis data relasional bertujuan menentukan berapa dan bagaimana struktur tabel yang akan digunakan dalam basis data. Selain itu ditentukan juga hubungan antar data, yang ditentukan dengan relational Integrity antar tabel.

\section{METODOLOGI PENELITIAN}

Tahapan pembuatan basis data untuk menunjang aktivitas pengelolaan daftar part (partlist), dimulai dengan mengumpulkan uraian tugas yang akan dilaksanakan. Dilanjutkan dengan menganalisis kebutuhan basis data dari sistem tersebut. Tahapan berikutnya merencanakan basis data logika dan basisdata fisik. Rangkaian tugas ini diakhiri dengan pembuatan prototipe dengan menggunakan perangkat lunak Delphi 3.

Metodologi perancangan basis data secara garis besar melalui beberapa tahapan, yaitu (3):

1. Rancangan logika basis data untuk basis data relasional.
a. Susun model data konseptual lokal dari user view

b. Susun model data logika lokal

c. Susun model data logika global

2. Rancangan fisik basis data dan penerapan untuk basis data relasional.

a. Ubah model data logika global ke sasaran DBMS

b. Rancang dan terapkan representasi fisik

c. Rancang dan terapkan mekanisme security ( keamanan)

d. Monitor sistem operasional

Dalam penulisan ini semua langkah di atas tidak dipresentasikan secara rinci, hanya langkah-langkah yang dianggap penting.

Dari pendalaman kegiatan pengelolaan daftar part yang terjadi pada perusahaan dapat digambarkan sebagai berikut:

1. Perusahaan memiliki beberapa bagian (unit kerja) yang mendapat tugas berbeda terhadap pengelolaan part.

2. Data yang berkaitan dengan daftar part (bill of material), adalah struktur part (article structure), data part (article).

Dari setiap informasi yang diperlukan pada setiap aktivitas selanjutnya dirinci Entity type (tipe entiti), Relationship type (tipe relasi), Attribute (atribut), dan Attribute domain (domain dari atribut), serta primary key. Rincian 
atribut relasi dan domain dari informasi tersebut digambarkan pada gambar 1 .

Diagram ini mencakup semua artikel dan kaitannya (relationship) satu dengan yang lain. Setiap artikel adalah elemen dari entiti "article", sedangkan setiap artikel ber-"hubungan" dengan artikel lainnya sebagai super-ordinate (induk) atau sub-ordinate (anak).Dan setiap "hubungan" adalah elemen dari entiti "Article-Structure". Hubungan dua entiti ini dengan rasio kardinal n:n.

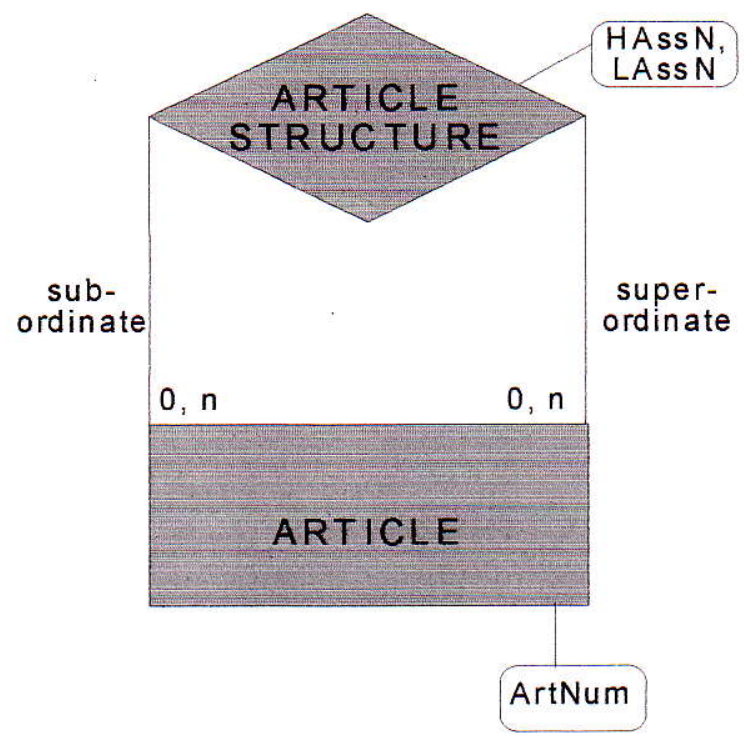

Gambar 1

ERM (Entity-Reltionship Model) dari BOM (9)

Tabel 1

Data artikel (article)

\begin{tabular}{|c|l|c|c|l|}
\hline No. Field & \multicolumn{1}{|c|}{ Nama Field } & $\begin{array}{l}\text { Jenis } \\
\text { Data }\end{array}$ & Ukuran & Keterangan \\
\hline \hline 1 & ArticleNumberID & $\mathrm{A}$ & 15 & nomor identifikasi (Primary key) \\
\hline 2 & XlstltemInBOM & $\mathrm{I}$ & & item pertama di BOM (Foreign \\
\hline 3 & ArticleNumberClass & $\mathrm{A}$ & 25 & nomor klasifikasi \\
\hline 4 & Quantity & $\mathrm{I}$ & & jumlah artikel \\
\hline 5 & PreviousVariantID & $\mathrm{A}$ & 15 & identifikasi varian sebelumnya \\
\hline 6 & PreviousVariantClass & $\mathrm{A}$ & 25 & kelas varian sebelumnya \\
\hline 7 & NextVariantID & $\mathrm{A}$ & 15 & identifikasi varian sesudahnya \\
\hline 8 & NextVariantClass & $\mathrm{A}$ & 25 & kelas varian sesudahnya \\
\hline 9 & UsedArticle & $\mathrm{n}$ & & rakitan sebelumnya yang memakai \\
\hline 10 & RouteNumber & $\mathrm{A}$ & 15 & refrensi ke rencana proses \\
\hline 11 & AssePlanNumber & $\mathrm{A}$ & 15 & nomor rencana rakitan \\
\hline 12 & VeriPlanNumber & $\mathrm{A}$ & 15 & nomor rencana verivikasi \\
\hline 13 & RawArticleID & $\mathrm{A}$ & 15 & identitas artikel bahan \\
\hline 14 & RawArticleClass & $\mathrm{A}$ & 25 & kelas artikel bahan \\
\hline
\end{tabular}




\begin{tabular}{|l|l|l|l|l|}
\hline 15 & MaterialNumber & $\mathrm{A}$ & 15 & nomor material \\
\hline 16 & Measurement & $\mathrm{n}$ & & berat \\
\hline 17 & Unit & $\mathrm{A}$ & 15 & satuan berat \\
\hline 18 & ArticleLength & $\mathrm{n}$ & & panjang artikel \\
\hline 19 & ArticleLengthAllo & $\mathrm{n}$ & & toleransi panjang artikel d \\
\hline 20 & ArticleWidth & $\mathrm{n}$ & & lebar artikel \\
\hline 21 & ArticleWidthAllo & $\mathrm{n}$ & & toleransi lebar artikel \\
\hline 22 & ArticleHeight & $\mathrm{n}$ & & tinggi artikel \\
\hline 23 & ArticleHeightAllo & $\mathrm{n}$ & & toleransi tinggi artikel \\
\hline 24 & ExtraPlacementPossible & $\mathrm{L}$ & & kemungkinan penempatan ekstra \\
\hline 25 & InHouseProduction & $\mathrm{L}$ & & diproduksi sendiri \\
\hline 26 & ArticleType & $\mathrm{a}$ & 20 & tipe artikel \\
\hline 27 & NormArticle & $\mathrm{L}$ & & normalisasi artikel \\
\hline 28 & NormNumber & $\mathrm{A}$ & 15 & nomor normalisasi \\
\hline 29 & ArticleDrawingID & $\mathrm{A}$ & 30 & identitas gambar artikel \\
\hline 30 & ArticleDrawingClass & $\mathrm{A}$ & 20 & klas gambar artikel \\
\hline 31 & StateOfModi & $\mathrm{A}$ & 15 & keterangan modifikasi \\
\hline 32 & StateOfWork & $\mathrm{A}$ & 15 & keterangan dikerjakan \\
\hline 33 & StateOfUsage & $\mathrm{A}$ & 15 & keterangan penggunaan \\
\hline 34 & ABCClass & $\mathrm{A}$ & 15 & klasifikasi ABC \\
\hline 35 & ArticleDescription & $\mathrm{A}$ & 50 & keterangan artikel \\
\hline 36 & Prismatic & $\mathrm{L}$ & & prismatik atau seimbang dinamis \\
\hline
\end{tabular}
Keterangan:
$\mathrm{A}=$ AlphaNumeric
$\mathrm{I}=$ Long Integer
$\mathrm{L}=$ Logic
$\mathrm{N}=$ Number

Tabel 2

Struktur artikel (article stucture)

\begin{tabular}{|c|c|c|c|c|}
\hline $\begin{array}{l}\text { No. } \\
\text { Field }\end{array}$ & Nama Field & $\begin{array}{l}\text { Jenis } \\
\text { Data } \\
\end{array}$ & Ukuran & Keterangan \\
\hline 1 & AssemblyNumber & I & & nomor rakitan (Primary key) \\
\hline 2 & Count & $\mathrm{I}$ & & $\begin{array}{l}\text { jumlah artikel penyusun } \\
\text { rakitan }\end{array}$ \\
\hline 3 & NextPositionBOM & $\mathrm{N}$ & & posisi berikutnya \\
\hline 4 & PreviousUsageOfArticle & $\mathrm{I}$ & & pemakaian sebelumnya \\
\hline 5 & ArticleNumberID & A & 15 & $\begin{array}{l}\text { nomor identitas artikel } \\
\text { (Foreign Key) }\end{array}$ \\
\hline 6 & ArticleNumberClass & A & 25 & $\begin{array}{l}\text { nomor klasifikasi artikel } \\
\text { (Foreign Key) }\end{array}$ \\
\hline 7 & SupperiorAssyID & A & 15 & $\begin{array}{l}\text { identifikasi rakitan induk } \\
\text { (Foreign Key) }\end{array}$ \\
\hline 8 & SupperiorAssyClass & $\bar{A}$ & 25 & $\begin{array}{l}\text { kelas rakitan induk (Foreign } \\
\text { Key) }\end{array}$ \\
\hline
\end{tabular}




\section{HASIL DAN PEMBAHASAN}

\section{A. Rancangan Basis Data Fisik}

Software yang digunakan untuk membuat sistem manajemen basis data (DBMS) adalah Paradok 7. Setelah pemilihan sistem menejemen basis data, berikutnya adalah pembuatan skema /alias (direktori dimana tabel-tabel basis data disimpan), dengan mengaktifkan menu alias manager pada aplikasi Database Desktop. Skema/alias ini selanjutnya akan disimpan pada konfigurasi engine basis data. Dengan adanya skema ini aplikasi yang dibangun akan mampu melacak dan mengakses tabel-tabel dari basis data ditempatkan dengan memilih skema/alias yang terdaftar pada konfigurasi engine basis data tersebut.

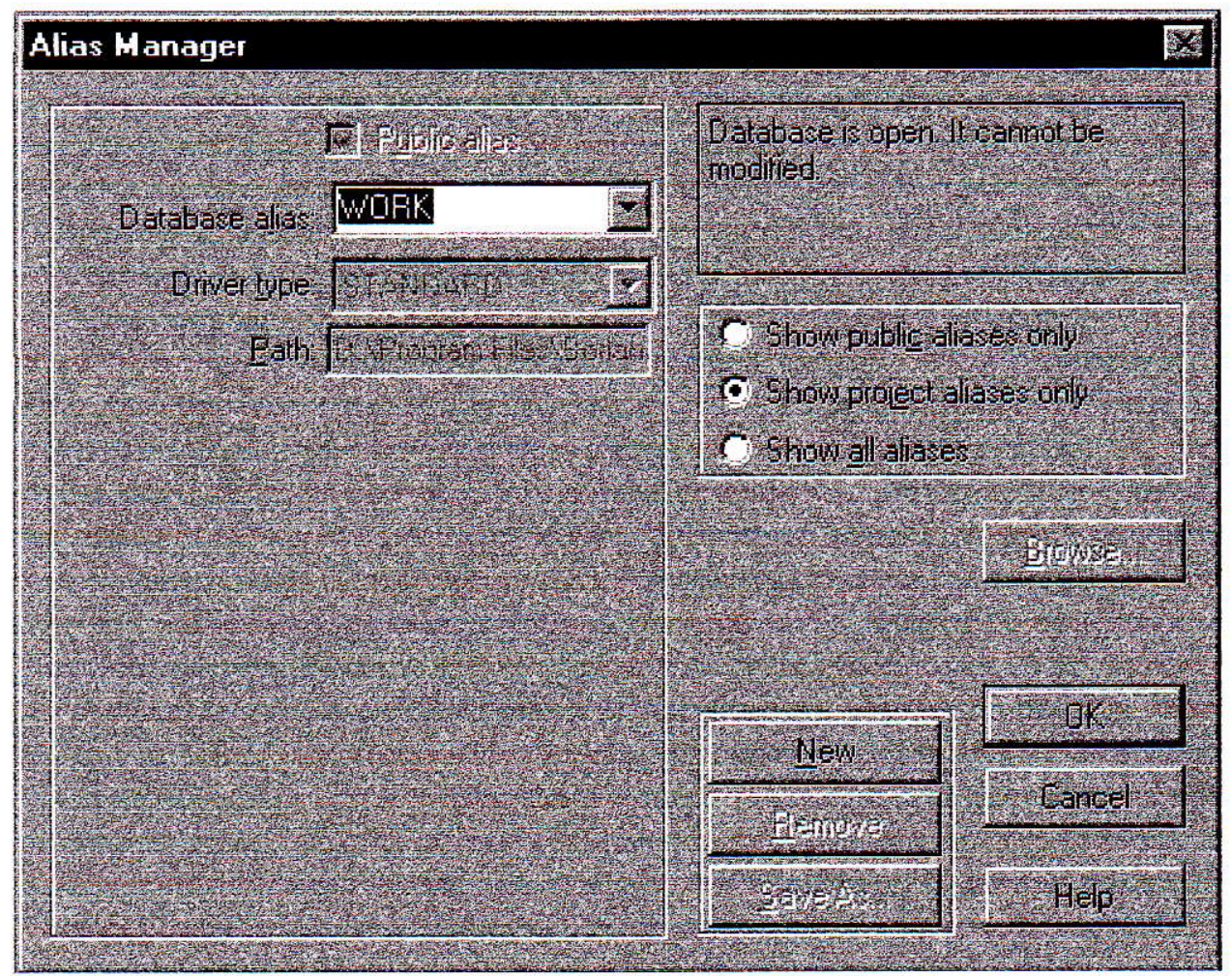

Gambar 2

Pembuatan skema/alias. 


\section{B. Rancangan Relasi Dasar}

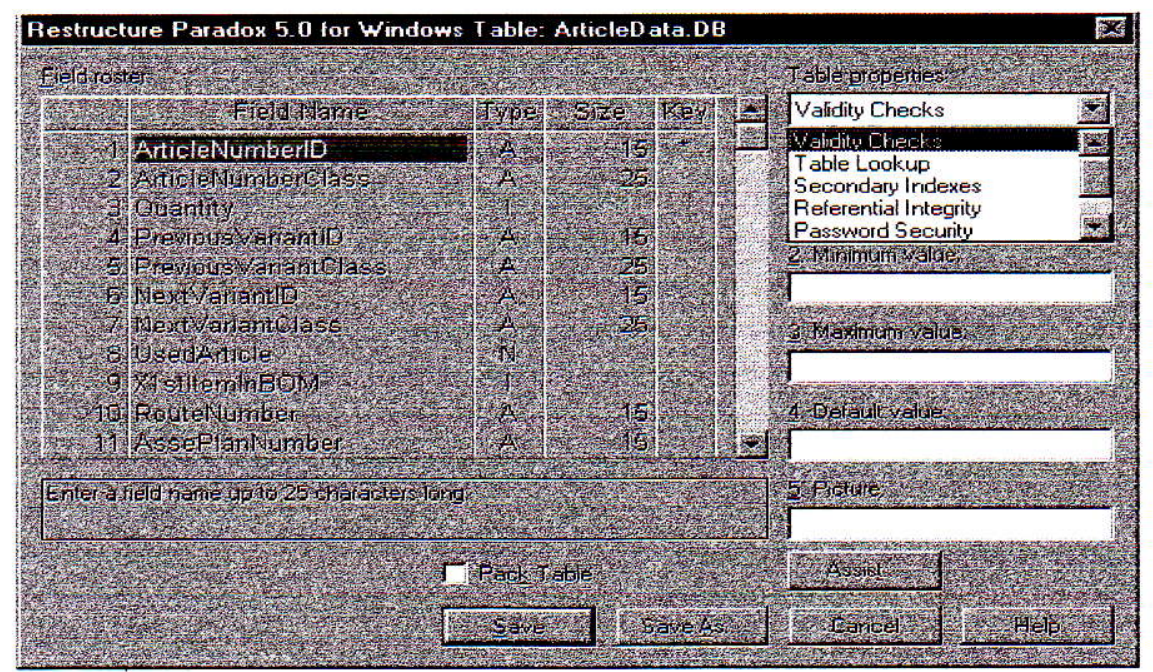

Gambar 3

Rancangan relasi dasar

\section{Rancangan Relational Integrity}

Perancangan aturan relasi antar tabel dilakukan dengan jalan mendefinisikan Entity Integrity dan Referential Integrity; yaitu child tabel ke parent tabel, dengan jalan membuat relasi Foreign key yang ada pada child tabel dengan primary key pada parent tabel. Pada tahap ini seluruh tabel telah memiliki relasi seperti yang telah dirancang pada tahap perancangan basis data logika.

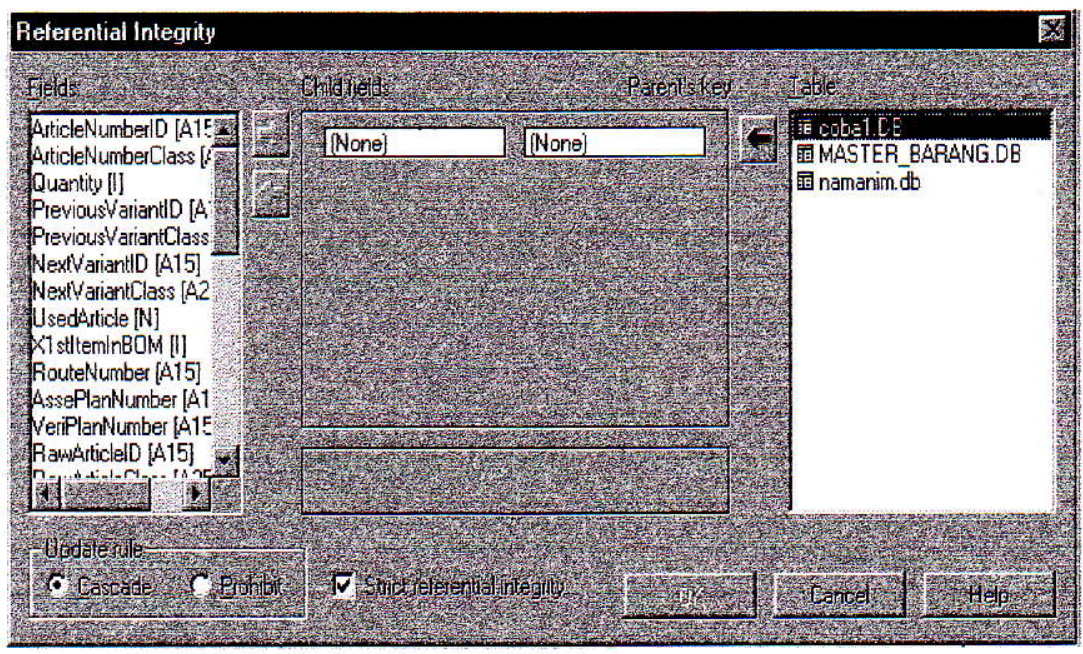

\section{Gambar 4}

Rancangan referential integrity. 


\section{Pemilihan Secondary Indexes}

Pemilihan Indeks Sekunder ini bertujuan untuk merancang urutan baris dari tuple, sesuai dengan indeks pada field /atribut yang dipilih, sehingga akan lebih mudah mengurutkan data.

\section{Rancangan "Graphical User Interface"}

\section{(GUI)}

Rancangan tampilan perlu memperhatikan aktifitas pemakai, sehingga kebutuhan informasi dan mengelola data bisa terpenuhi, yaitu:

* Merancang dan menampilkan daftar part/article

* Melihat struktur part

Aplikasi untuk memasukkan data dan mengubah data

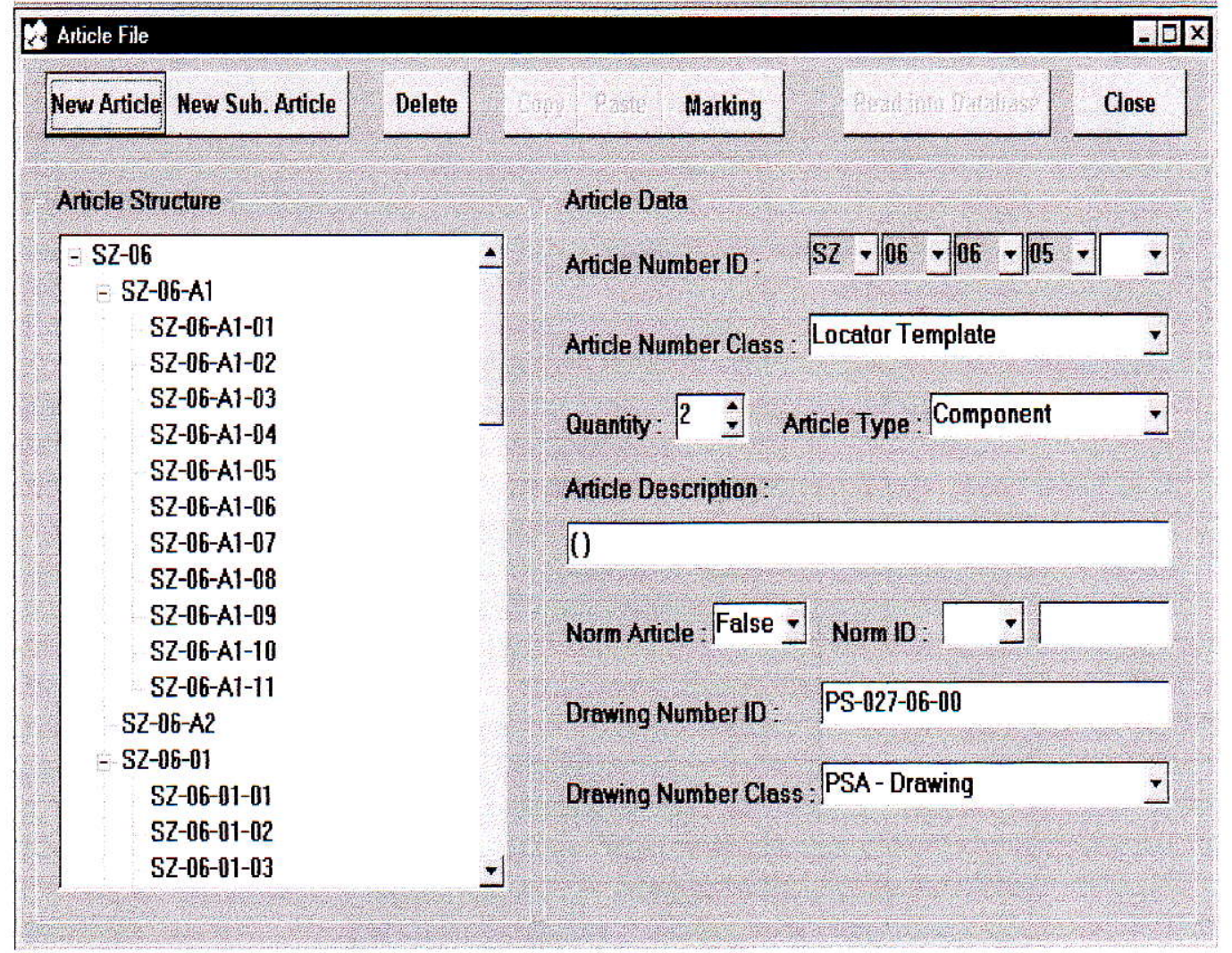

\section{Gambar 5}

Tampilan utama "Bill of Material Management". 


\section{Bill of Waterial Wanagement}

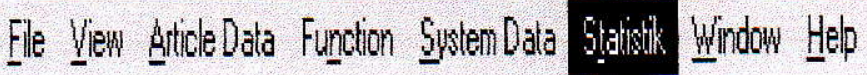
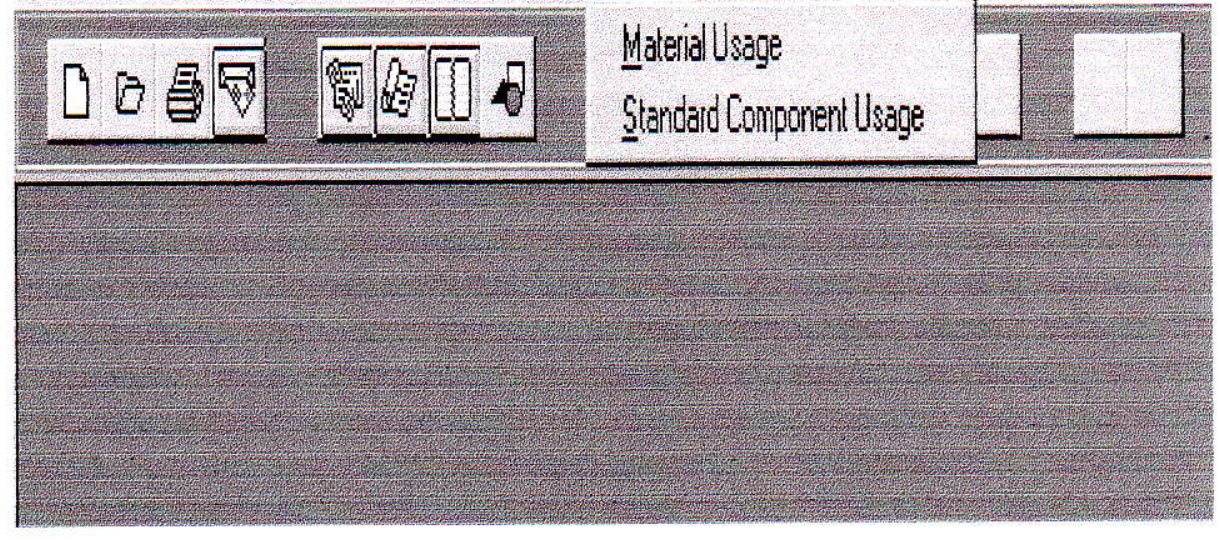

Gambar 6

Fasilitas untuk merancang daftar dan struktur article.

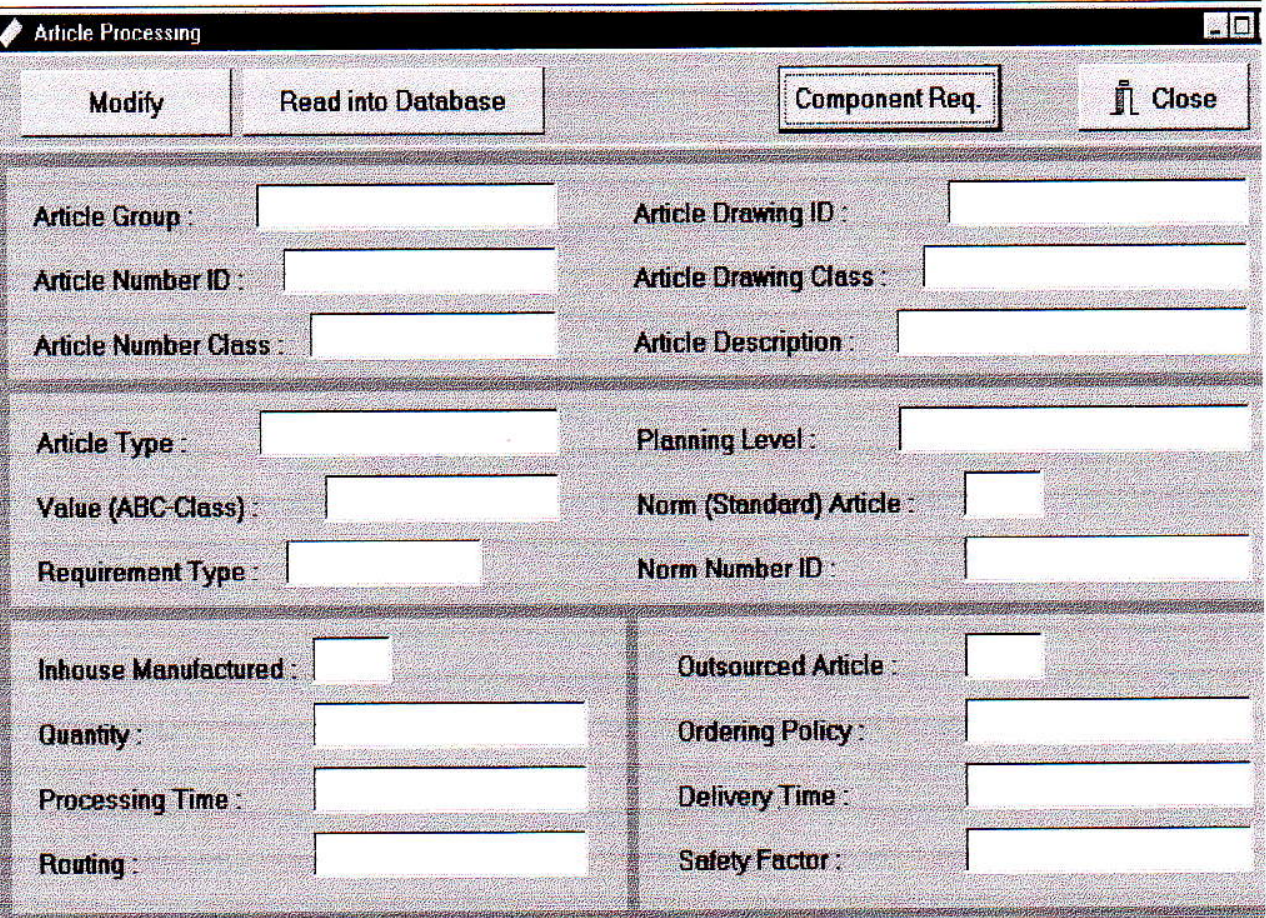

Gambar 7

Navigasi untuk modifikasi data dan article structure. 


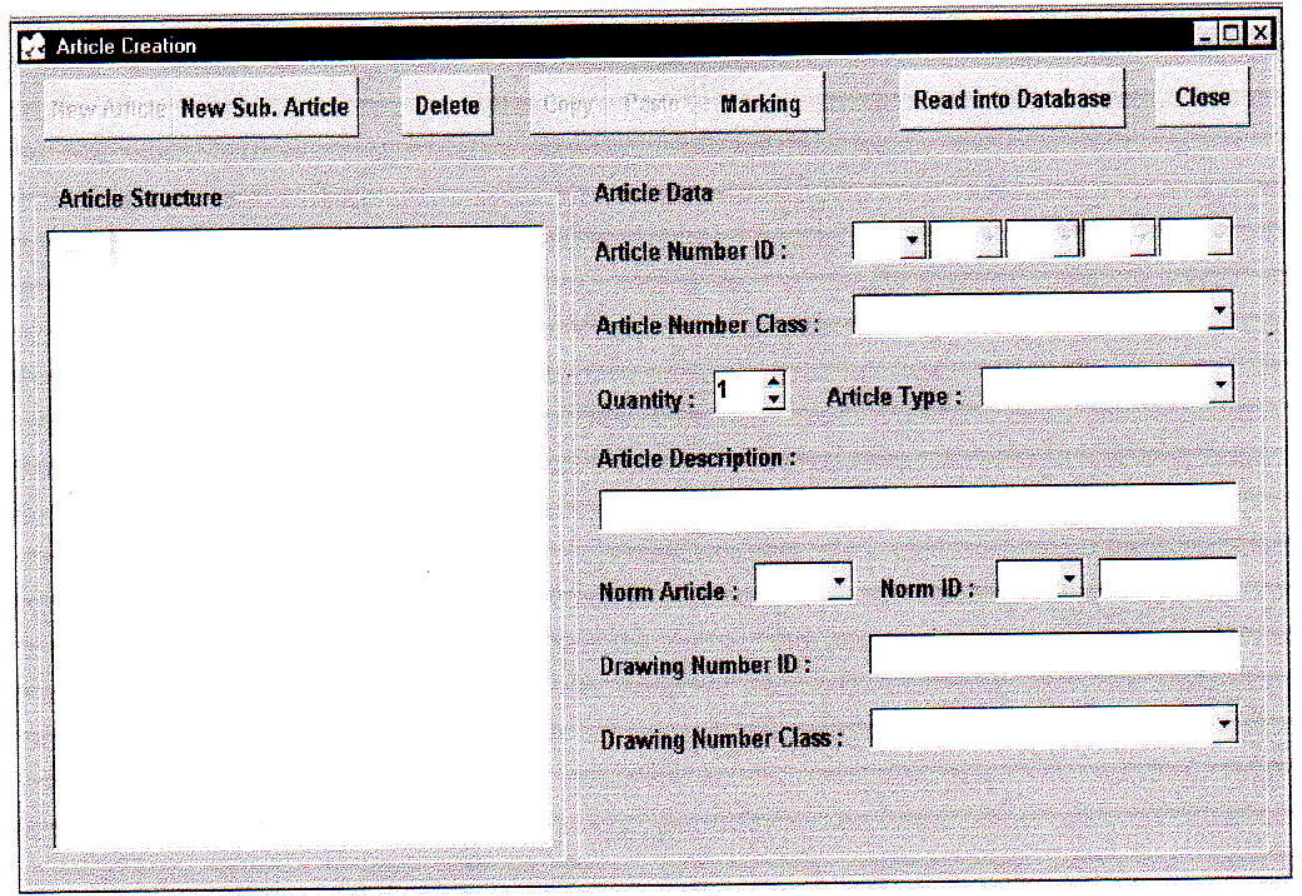

Gambar 8

Tampilan data article

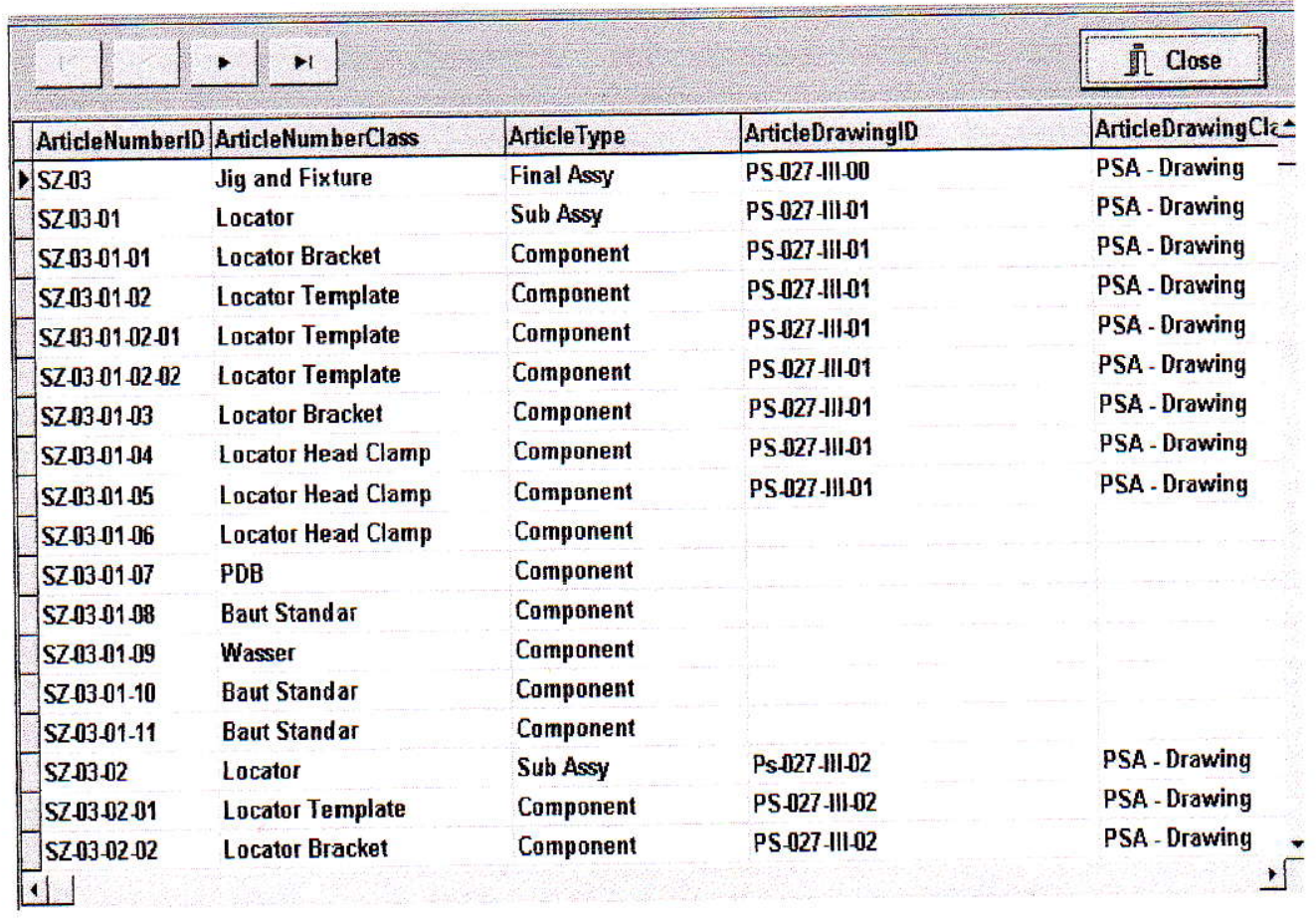

\section{Gambar 9}

Menampilkan mask article processing (belum aktif), dengan melakukan 'klik' dua kali atau klik menu. 


\section{KESIMPULAN}

Kesimpulan umum dari penelitian ini, dengan mengelompokkan sesuai pokok bahasan, sebagai berikut:

- Standardisasi bracket di perusahaan manufaktur, dari segi teknologi dan segi ekonomi layak diterapkan.

- Penggunaan basis data sangat membantu bagian produksi,bagian pemasaran dan bagian gudang untuk mengelola part yang berjumlah dan bervariasi banyak.

- Basis data mempermudah penelusuran sejarah part dalam suatu proses produksi, serta melihat kondisi bahan dan jumlah part yang tersedia setiap saat dengan cepat. Yang sangat diperlukan dalam salah satu klausul ISO 9000.

- Basis data membantu bagian perakitan untuk mencari dan memilih part yang akan dirakit dengan cepat dalam sebuah proses produksi.

\section{DAFTAR PUSTAKA}

Björke Ö;1978, $\quad$ Computer-Aided Tolerancing, Tapir Publishers, Norway,

Chatab, N. ; 1996, Panduan Penerapan dan

Sertifikasi Sistem Manajemen Mutu ISO 9000, PT. Elex Media

Computindo, Jakarta, Indonesia.

Connolly, T.,Begg, C., Strachan, A.; 1996,

Database Systems, Addison-Wesley

Publishing Co. Inc, Singapore,
Erens, F.J.; 1996, The Synthesis of Variety, Thesis, Technische Universiteit Eindhoven, Netherlands.

Holt, D.R.; 1992, Integrating Manufacturing Engineering

Systems, McGraw-Hill, USA.

Kalpakjian, S.; 1995, Manufacturing Engineering and Technology, $3^{\text {rd }}$ Ed., Addison-Wesley Publishing Co., USA.

Rochim, T.; Spesifikasi Geometris, Metrologi Industri dan Kontrol Kualitas, Diktat Kuliah, Lab. Metrologi, ITB.

Scheer, A.-W.; 1994, Business Process Engineering, $2^{\text {nd }}$ Edition, SpringerVerlag, Germany.

Singarimbun,M.,Effendi,S.; 1991, Metode Penelitian Survai, LP3ES, Jakarta.

Wiendahl,H.-P.; 1995, Load Oriented Manufacturing Control, Springer-

Verlag Hannover, Germany.

Wirjomartono, S.H.; 1979, The Influence of Standardization on Productivity of The Engineering Industry of Indonesia, Disertasi Doktor, Penerbit ITB.

,ISO Standards Handbook 12, 1991, Technical Drawings, 2 nd Ed., International Organisation for Standardization, Switzerland, 